\title{
Class I Restoration
}

National Cancer Institute

\section{Source}

National Cancer Institute. Class I Restoration. NCI Thesaurus. Code C52572.

Reconstruction of the occlusal surface of a tooth. 